ISSN No. 0974-035X

An Indexed, Refereed \& Peer Reviewed Journal of Higher Education

Towards Excellence

UGC-HUMAN RESOURCE DEVELOPMENT CENTRE,

GUJARAT UNIVERSITY, AHMEDABAD, INDIA

\title{
A STUDY OF PBL USING TECHNOLOGY FOR THE STUDENTS OF GUJARAT
}

\section{Mr. Kamlesh Joshi}

\section{ABSTRACT}

Various methodologies have been applied in terms of developing teaching and learning in Gujarat. Methods like traditional method, Grammar translation method, Situational functional method, Experimental method, Direct method, Structural method etc. have been pioneer in enhancing the learning-teaching across the India even in Gujarat. Yet remarkable development in pedagogy has not been observed due to endless number of reasons, such as inefficiency of the implementer and implementation of appropriate method.

Many methods and approaches have been implemented for the development of English based psychology and pedagogy of teaching. English subject becomes compulsory in Gujarat from std 5th to Graduate level. Students learn English for 10 years yet many of them lack communicative competence. One of the chief reasons for it is that most of the teachers use old traditional method in the classroom teaching. Most of them are not ready to accept the new teaching methods and approaches in the classroom teaching. Many approaches like Communicative Language Teaching, Project Based Learning, and Co-operative Learning etc. are the need of the time. Good results are produced after using new approaches in the classroom.

If Technology supported Project Based Learning is put forward for piloting the students learning, desirable goals can be achieved. Even this Technology supported Project Based Learning make them competent with 21 st century skills, like digital age literacy, inventive thinking, interactive communication, social and personal skills etc. which is the soul requirement of this era. 
Towards Excellence: An Indexed, Refereed \& Peer Reviewed Journal of Higher Education / Mr. Kamlesh Joshi / Page 65-74

Key-Words: - Technology, Learning, Communicative Competence, 21st Century Skills, Project Based Learning, Methods, Approaches, Communicative Language Teaching, Cooperative Learning etc.

\section{Introduction}

Various methodologies have been applied in terms of developing teaching and learning in Gujarat. Methods like traditional method, Grammar translation method, Situational functional method, Experimental method, Direct method, Structural method etc. have been pioneer in enhancing the learning-teaching across the India even in Gujarat. Yet remarkable development in pedagogy has not been observed due to endless number of reasons, such as inefficiency of the implementer and implementation of appropriate method. English subject becomes compulsory in Gujarat from std $5^{\text {th }}$ to Graduate level. Students learn English for 10 years yet many of them lack communicative competence. One of the chief reasons for it is that most of the teachers use old traditional method in the classroom teaching. Most of them are not ready to accept the new teaching methods and approaches in the classroom teaching. Many approaches like Communicative Language Teaching, Project Based Learning, and Co-operative Learning etc. are the need of the time. Good results are produced after using new approaches in the classroom.

"Studies show that relative to traditionally taught students who participate in Project Based Learning are more motivated, demonstrates better communication and teamwork skills and have a better understanding of issues and how to apply their learning to realistic problem." (Davis 219)

If Technology supported Project Based Learning is put forward for piloting the students learning, desirable goals can be achieved. Even this Technology supported Project Based Learning make them competent with $21^{\text {st }}$ century skills, like digital age literacy, inventive thinking, interactive communication, social and personal skills etc. which is the soul requirement of this era.

In this study, the researcher made an attempt to use both pioneer methods to look out the vital difference at the end of try-out. This study was applied on the students of L P Savani School $8^{\text {th }}$ STD.

\section{The problem}


The title of the investigation is:

“A STUDY OF PBL USING TECHNOLOGY FOR THE STUDENTS OF GUJARAT"

\section{Definition of Terms}

\section{Project Based Learning}

Project-based learning is a comprehensive instructional approach to engage students in sustained, cooperative investigation. It focuses on the central concepts and principles of a discipline, involves students in problem solving investigations and other meaningful tasks, allows students to work autonomously to construct their own knowledge, and culminates in realistic products.

In disciplines other than second and foreign language, the Buck Institute for Education (BIE), an American research and development organization, defined PBL as "a systematic teaching method that engages students in learning knowledge and skills through an extended inquiry process structured around complex, authentic questions and carefully designed products and tasks"( Markham 4).

\section{Technology}

Technology is the usage and knowledge of tools, techniques, craft, system or methods of organization in order to solve a problem or serve some purpose in terms of pedagogy.

\section{Delimitation}

The research study aims at enhancing $21^{\text {st }}$ century skills and other LSRW skills of the students through e-tasks like internet research and project work with use of this methods. The study is considering a group of students of $8^{\text {th }}$ standard of L P Savani Surat School, Gujarat. In this study, various aspects of the students will be focused to develop to see the difference under this method.

\section{Research Questions}

This study will seek to answer the following major questions. 
1. Can Technology Supported Project Based Learning help students to understand the concept of their subject lesson?

2. Can Technology Supported Project Based Learning help students to enhance students' $21^{\text {st }}$ century skills?

3. Can Technology Supported Project Based Learning develop the students collaborative learning?

4. Can Technology Supported Project Based Learning be used to build interaction among students?

5. Can Technology Supported Project Based Learning enable the learners to be creative?

\section{Objectives}

1. To find out the mean achievement pre-test scores of the students.

2. To find out the mean achievement post-test scores of the students.

3. To find out the effectiveness of TPBL in terms of students' achievement scores.

\section{Hypotheses}

1. There will be significant difference between boys and girls mean achievement pre-test scores.

2. There will be significant difference between boys and girls mean achievement post-test scores.

3. There will be no significant difference between boys and girls mean achievement pre-test and post-test scores.

\section{Significance of the Study}

None can challenge the status of English as a world language and as an important school subject. Many developments in the field of educational technology have enriched our teachinglearning process. English language teaching has witnessed a wide range of knowledge and reinforcement on the part of teachers and educators. But at the same time it has created the need of serious considerations of how English should be taught. The present study threw a 
considerable degree of light in this regard. According to the investigator the results of the study are useful in the following ways.

\section{Research Methodology}

The present study is basically an experimental study. Experimental study provides a good number of designs. The decision of selecting research design is mainly based on the nature of the study. The investigator studied the effectiveness of Technology supported Project Based Learning fort the students of $8^{\text {th }}$ Standard GSEB board First Language.

\section{Population}

The researcher studied the effectiveness of the Technology Supported Project Based Learning for English language teaching on the basis of selected teaching units of std. $8^{\text {th }}$ (English medium). Hence the students of Gujarat studying in std. $8^{\text {th }}$ (of English medium) were included in the population. Looking to the limitation of time and circumstances the students of whole Gujarat state studying in school could not be included in the experiment. Therefore, the investigator delimited the population of the study which comprised of the students of std. $8^{\text {th }}$ of English medium school: L P Savani School, Surat.

\section{Sample of the present study}

The investigator conducted an experiment in the school. The investigator applied two different treatments in the forms of the approaches selected for the study. Here, the investigator did not use the sampling technique which allowed equal probable chances for the subjects to be selected in the sample. The sampling technique where chances of selection rest on the investigator's decision was used for the present study. The investigator therefore selected the $8^{\text {th }}$ std using 'the convenient sampling technique'. The detail of the sample of the study is shown in the table.

\section{Sample of the present study}




\begin{tabular}{|c|c|c|c|}
\hline Gender & Boys & Girls & Total \\
\hline Number of students & 20 & 20 & 40 \\
\hline
\end{tabular}

It is observed from the table that the investigator selected a group of forty students from $8^{\text {th }}$ std. This study was conducted in L P Savani School, Surat.

This course has duration of one moth and is compulsory for all students of L P Savani School, Surat, $8^{\text {th }}$ standard (GSEB English medium).

\section{Selection and Equalization of Teaching Units}

According to the research design the investigator had to apply different treatments of teaching English. He selected two teaching units to teach the group through two different approaches. Following aspects were considered in selecting the teaching units.

1. Topics of teaching units were selected from the English text book of GSEB (first language) of std VIII.

2. Topics were selected from the teaching points given in the texts.

3. The difficulty level of all the teaching points was kept equal.

4. Changes were made wherever the difficulty level of a particular topic differed from that of the other .

5. The duration of the teaching of the topic was fixed according to the unit.

\section{Tools of Research}

The investigator did not use any ready tool, prepared by another researcher. He wanted to test student achievement in English after teaching them through two different approaches. According to the research design investigator needed pretest- posttest to test students' achievement in English.

\section{Construction of 'Teacher Made Test'}

The investigator thoroughly studied the teaching materials before preparing "teacher made test'. He also reviewed testing materials on language. The investigator held meetings with the 
experts and decided the weightage of marks, the format of the test and the form of the test. After detailed discussion with them it was decided to follow the following criteria to prepare the "teacher made test'.
a) Objectives of the study.
b) Different skills like LSRW also to be tested.
c) Each test was prepared consisting of forty marks.
d) No time limit was fixed.
e) Weightage was to be kept uniformly.
f) Different objectives for listening, speaking, reading and writing were kept in consideration.

\section{Data Collection}

Technology supported Project Based Learning is used to make effective teaching in the classroom. The students were given a pre-test before the experiment and a post-test after the experiment. Both, the pre-test and post-test had the similar items for the students of the school. The pre-test was taken to get the impact of traditional method of teaching. Each test was of 40 marks. The difference between pre-test and post- test gave the actual idea whether there is a significant improvement in their English language skills.

\section{Data Analysis}

Having collected data in the form of pretest and post test score, it was divided into different groups according to the objectives of the study. To study the effectiveness of the Technology Supported Project Based Learning to develop LSRW skills of the students, the mean difference of students' achievement was calculated.

To compare the significant difference between the mean achievements of the score of the students't-test technique was used.

\section{Findings of the Study}

The finding of the study is given below. 
In the treatment two lessons were taught using two different methods to same group. The result of this experiment is as under.

Technology Supported Project Based Learning found more effective than the traditional method of teaching to English Language in terms of students' achievement in English.

$>$ Technology Supported Project Based Learning found more effective than the traditional method of teaching to English Language in terms of students' achievement in listening, speaking, reading and writing skills of English.

It means that Technology Supported Project Based Learning is more effective to improve listening, speaking, reading and writing skills of English language.

\section{Recommendations for Further Researches}

Recommendations for further researches in the area of ELT are as under.

A study of effectiveness of using Technology in the classroom may be taken.

$>$ A study of various methods applying with Project Based Learning in support of technology may be taken.

$>$ A study of effectiveness of different techniques used under the Technology Supported Project Based Learning may be taken.

$>$ A survey of drawbacks and useful features of the traditional approach can be taken as a study.

$>$ A study for the improvement of the judicial use of mother tongue as a classroom resource may also be taken to support traditional approach.

$>$ There are more than one models of the Project Based Learning to ELT. A parallel study of the effectiveness of these different models can be taken. 
Towards Excellence: An Indexed, Refereed \& Peer Reviewed Journal of Higher Education / Mr. Kamlesh Joshi / Page 65-74

\section{Bibliography}

Beckett, G. H., \& Slater, T. "The Project Framework: a tool for language, content, and skills integration.” ELT Journal, 59.2 (2005). Print.

Beckett, Gulbahar H., and Miller, Paul Chamness. Project-based Second And Foreign Language Education: Past, Present, And Future. United State of America: In formation Age publishing Inc. 2006. Print.

Brooks, J. and Brooks, M. The Case for Constructivist Classrooms. Alexandria, VA: ASCD. 1999. Print.

Chen, Milton, and Lucas, George. Education Nation: Six Leading Edges of Innovation in Our Schools. United State of America: Jossey-Bass Publishing. 2010. Print.

Davis, R. S., and Armstrong, H. “Using a Foreign Language Beyond the Classroom.” The Language Teacher. 19. 5(1995): 219. Print.

Davis, Barbara Gross. Tools for Teaching. United State of America: Jossey-Bass Publishing. Second Edition. 2009. Print.

Fried-Booth, D. L. Project Work. Oxford: Oxford University Press. 2002. Print.

Gagne, R. M. The conditions of learning._New York: Holt, Rinehart \& Winston. 1965. Print

Gülbahar, Y., and Tinmaz, H. "Implementing Project-Based Learning and E-Portfolio Assessment in an Undergraduate Course". Journal of Research on Technology in Education. 38. 3 (2006): 309-320. Print.

Kent, Moors. The Vega Factor. Wiley John and Sons, 2011. P.414. Print.

Larsen-Freeman, D. Techniques and Principles in Language Teaching. New York: Oxford University Press.:1986. Print.

Mooney, C. Theories of childhood. St. Paul, MN: Redleaf Press. (2000). Print. 
Towards Excellence: An Indexed, Refereed \& Peer Reviewed Journal of Higher Education / Mr. Kamlesh Joshi / Page 65-74

Markham, T., Mergendoller, J., Larmer, J., \& Ravitz, J. Project Based Learning Handbook. Canada: Buck Institute for Education. Buck Institute Publishing: 2003. Print.

OECD glossary of statistical terms. Organisation for Economic C0-operation and Development. OECD Pub. 2008. Print.

Patel, P. Impact of Technology Integrated Project Based Learning on Students at the Higher Secondary level (Second Language). Diss. Sardar Patel U, India, 2004. Print.

Paliwal, A. K. Communicative Language Teaching. Jaipur: Surabhai Publications. 2000. Print.

Roblyer, M. D. Integrating educational technology into teaching. Upper Saddle River, NJ: Merrill Prentice Hall. 2003. Print.

Solomon, G. "Project-Based Learning: a Primer." Technology \& Learning. 23(2003). Print.

Schlemmer, Phil., and Schlemmer, Dori. Teaching Beyond the Test: Differentiated Project-based Learning. United State of America: Free spirit publishing inc. 2008. Print.

Welsh, J. A. An Exploration of Project-Based Learning in Two California Charter Schools. EdD Thesis. University of Southern California, 2006. Print.

Welsh, Jennifer Alexandra. An Exploration of Project-based Learning in Two California Charter Schools. University of Southern California: Pro-quest Information Publishing. 2006. Print.

\section{Web sources:}

Buck Institute for Education. Overview of project based learning. Web 31 Jan 2012, from http://www.bie.org (2002).

\section{Mr. Kamlesh Joshi \\ PhD Scholar}

\section{Gujarat Technological University}

